\title{
On confluence and contestation in the Orinoco interaction sphere: the engraved rock art of the Atures Rapids
}

Philip Riris*

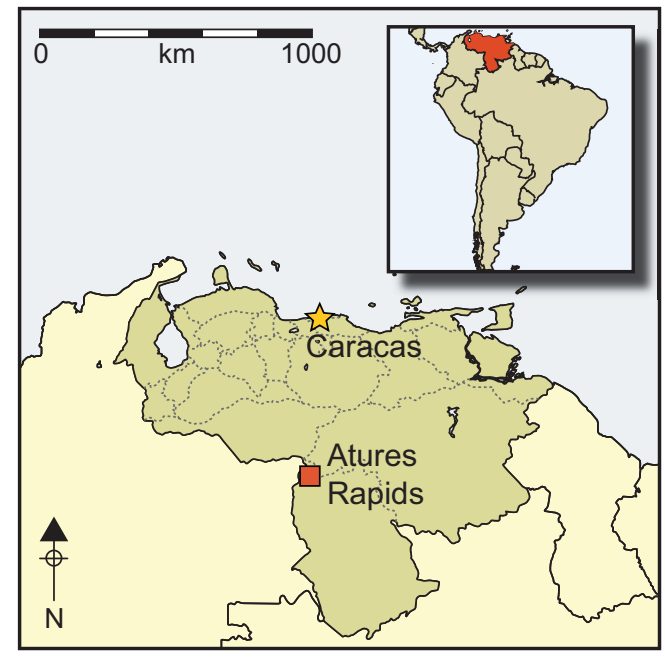

The Atures Rapids have long been considered a major point of confluence in the Middle Orinoco landscape, Venezuela. This has been underlined by newly discovered rock art panels on islands within the Rapids and on the margins of the Orinoco River. The panels were recorded photographically and photogrammetrically, and the spatial organisation and taphonomic factors affecting the corpus were investigated. The rock art was also examined in the context of established models of chronology and authorship. Placing the corpus in relation to archaeological and ethnographic evidence from Amazonia and the Guianas emphasises how the Atures Rapids structured preColumbian and Colonial contact between diverse groups in lowland South America.

Keywords: Venezuela, Orinoco, Yuruparí complex, petroglyphs, aerial photogrammetry

\section{Introduction}

This article presents new findings of engraved rock art in the Atures Rapids of Amazonas state in Venezuela (Raudales de Atures, henceforth the Rapids), and offers the opportunity for new insights into their archaeological and ethnographic context. Pre-Columbian art has a long history of study by naturalists and scientists travelling the Orinoco, and has been the subject of archaeological research in the region for over half a century (von Humboldt 1810; Chaffanjon 1889; Koch-Grünberg 1921, 2010[1907]; Cruxent 1950, 1953, 1955; Tavera-Acosta 1956; Sujo Volsky 1975; Scaramelli 1992; Greer 1995; Costas Goberna et al. 1996; Tarble de Scaramelli \& Scaramelli 2010). The Rapids are historically reported as the home of the native Adoles (del Rey Fajardo 1966, 1974), from which the later

* Institute of Archaeology, University College London, 31-34 Gordon Square, London WC1H OPY, UK (Email: p.riris@ucl.ac.uk). 
toponym of 'Atures' derives. Early missionary sources state that the Adoles were speakers of a Sáliban language, and had sizeable settlements on the islands within the Rapids (Gumilla 1945[1745]; Gilij 1965[1782]). The Rapids are especially notable for being the last point at which the Orinoco is easily navigable by boat. The physical barrier they form, as well as their intense history of contact through the Colonial period, has led to the suggestion that they are a natural fulcrum of interaction between the prehistoric upper Negro/Amazonia, the Guianas, and the Llanos to the west (Ojer 1960; Gassón 2002).

Petroglyphs (rock engravings) of the Middle Orinoco River have featured in regional reviews for several decades (Tavera-Acosta 1956; Sujo Volsky 1975; Dubelaar 1986). Yet systematic survey of engravings on a scale comparable to neighbouring regions remains unrealised here (see Reichel-Dolmatoff 1978, 1987; Pereira 2001; Koch-Grünberg 2010[1907]; Valle 2012). Conversely, more comprehensive studies of pre-Columbian pictographs (rock paintings) hint that the practice of rock art creation has considerable time-depth (see Scaramelli 1992; Greer 1995; Tarble \& Scaramelli 1999). Supported by the long history of exploration along the river, the information presented here substantially broadens the focus of study beyond well-known terra firme sites, such as Cerro Pintado (see Tavera-Acosta 1956). This represents a major step towards an enhanced understanding of the role of the Orinoco River in mediating the formation of pre-Conquest social networks throughout northern South America (Lathrap 1970; Boomert 2000; Gassón 2002; Zucchi 2002, 2010). Systematic surveys undertaken along the Rapids allow us to propose that the style and content of the engraved rock art corpus implicate it in wider webs of shared indigenous conceptions of cosmology and ritual throughout the pre-Columbian and Colonial periods (Boglar 1976; Reichel-Dolmatoff 1978; Williams 1985; Overing 1996). Through examination of a large corpus of riverine engravings, this study introduces significant new information to improve our understanding of the connectivity evident in pre-Columbian iconography across northern South America.

\section{Context: the Atures Rapids within the Middle Orinoco}

The Rapids are an ethnic, linguistic and cultural convergence zone. This is demonstrated by the presence of several distinct linguistic stocks that originate from elsewhere. These include several groups of Arawakan- (Curripaco, Piapoco, Baré) and Carib- (Mapoyo, Ye'kuana) speakers (Gassón 2002; Zucchi 2010). Some of these, such as the Hiwi (Guahibo), are probably historic migrants to the study area (Zent 1992; Tarble de Scaramelli 2012). The presence of Sáliba-speaking groups, such as the Piaroa (Wothuha) and the historic Adoles, may, by contrast, be of a much deeper antiquity (Zent 1992). By the mid eighteenth century, these groups had retreated inland and the missions remained largely populated by Arawak speakers (see Gumilla 1945[1745]; Gilij 1965[1782]). Each indigenous group will have, at different times, contributed to the overall cultural mosaic of the Middle Orinoco (Gassón 2002). Authors as early as Koch-Grünberg (writing in 1907) posited that the preColumbian artistic corpuses could indicate where interactions between diverse groups of people had taken place along the course of the river, suggesting that exchange occurred via major waterways in this vast region. Rock engravings may be included in this concept of embeddedness in broader-scale patterns, as many motifs are similar or identical to others (C) Antiquity Publications Ltd, 2017 
along the Orinoco and into neighbouring areas (Williams 1985: 378; Dubelaar 1986; Pereira 2001; Haviser \& Strecker 2006; Valle 2012).

Archaeologists continue to debate the scale and antiquity of contact between the LlanosGuyana-Amazonia-Caribbean region via the Orinoco and the extent to which this contact may explain the spread and endurance of ceramic traditions and ethnolinguistic groups (Boomert 2000; Gassón 2002; Zucchi 2002, 2010; Hornborg 2005; Rostain 2014). Archaeological investigations on the islands in the Rapids have, for example, successfully documented the presence of several major ceramic traditions, possibly insinuating millennia of continuous occupation (Lozada Mendieta et al. 2016). Within this broader context, the Rapids are recognised as a hotspot with a high abundance and diversity of rock art between the Maipures Rapids upstream and the Meta confluence with the Orinoco. It has been proposed that this region formed a "special area" within the Orinoco-Amazon interaction zone (Dubelaar 1986: 126), as downstream petroglyph sites only become more abundant after the Apure confluence, while engravings are sparsely reported upstream until the Casiquiare distributary (Sujo Volsky 1975; Dubelaar 1986). The rocky Rapids also contrast with the scarcity of large islands outside the middle course of the Orinoco. Against this complex backdrop, it is imperative to understand it not only as a landscape of confluence, but also one of contestation.

\section{Recording with computational photographic techniques}

Rock art was recorded on five islands (Figure 1) and their environs, including exposed bedrock outcrops (Raudales Wayuco, Yavarivén and Zamuro) within the Rapids themselves. The latter was made possible by historically low water levels in the Orinoco during February 2015 (Figure 2). These areas were targeted based on prior knowledge (F. Scaramelli pers. comm.), and were subsequently surveyed systematically. The geographic coordinates of all encountered panels were recorded, and the panels themselves were photographed with a DSLR camera and $80 \mathrm{~mm}$ scale. In addition to the painted and engraved rock art, several flat outcrops (lajas) bore numerous cupules and axe polishers segregated from the other engravings (Figure 3), thereby adding to the small quantity previously documented on Cotúa (Cruxent 1950). Cupules were also encountered alongside petroglyphs on earthbound boulders within large, multi-period surface scatters. These cap deeply stratified $(>2 \mathrm{~m})$ and continuous archaeological layers that span from early Ronquinoid to late Arauquinoid deposits (Lozada Mendieta et al. 2016). The largest cluster of cupules is located on the northern tip of Picure Island, and comprises 56 grooved axe polishers adjacent to 40 cupules.

Eight principal groups of engraved rock art in the Rapids can now be defined (Table 1), the largest of which is on a north-facing outcrop on Picure Island $\left(304 \mathrm{~m}^{2}\right.$, containing at least 93 individual motifs). Here, the conspicuous size of some animal motifs $\left(>5 \mathrm{~m}^{2}\right.$ for a single engraving, in one case) and the panel itself would render sketching prohibitively time-consuming and liable to suffer from gross recording errors. Hence, two orthomosaics were generated from low-altitude aerial photographs taken with a Phantom 2 Vision+ drone (Figures 4-5), scaled to ground-level benchmark photographs. This provided a highresolution in situ record of this group of panels. Three motifs from Picure and a composite 


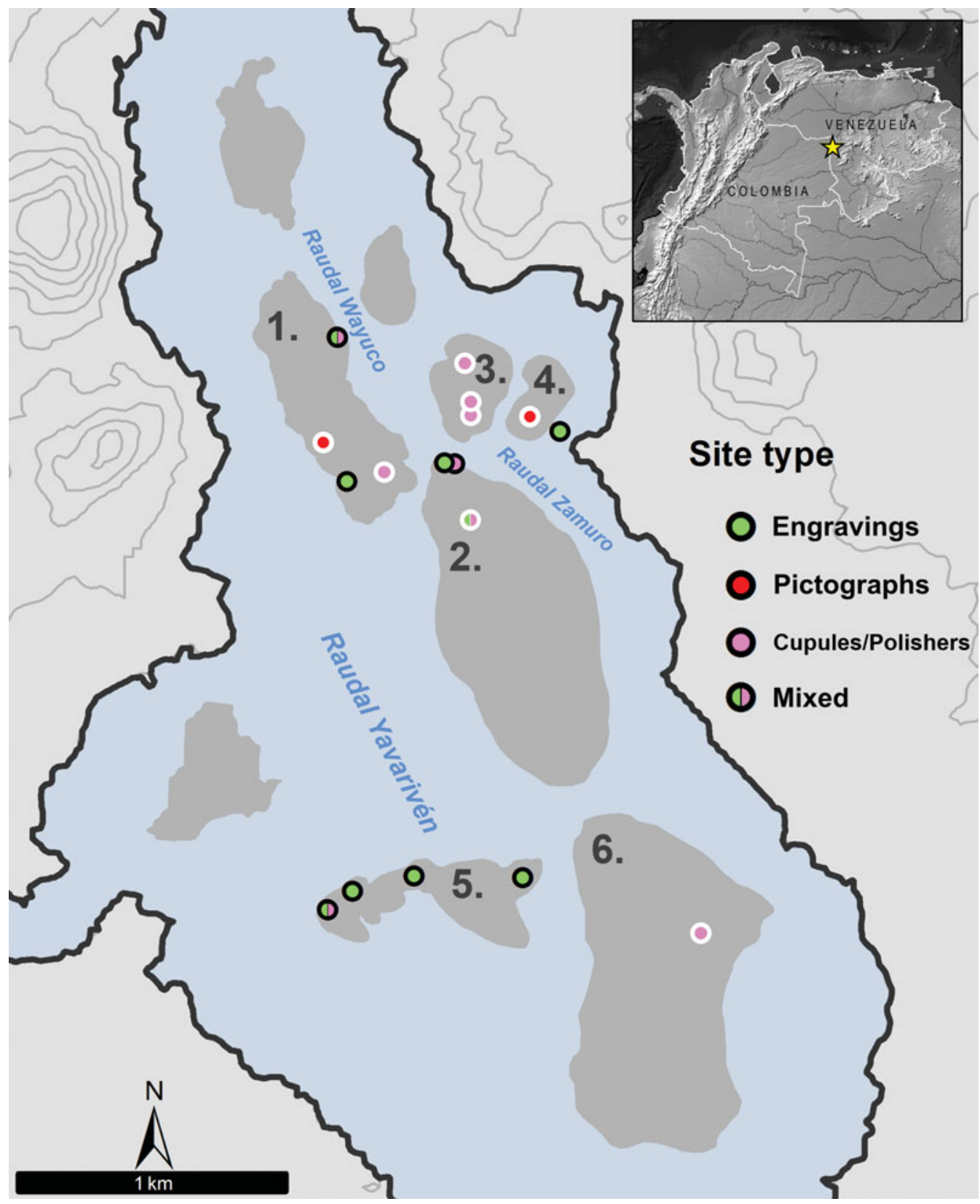

Figure 1. The five main areas surveyed: 1) Cotúa and Raudal Wayuco; 2) Picure; 3) Zamuro; 4) Viboral and Raudal Zamuro; 5) Raudal Yavarivén; 6) Sardina. Points with black outlines usually inundate, while white outlined points very rarely inundate.

(C) Antiquity Publications Ltd, 2017 


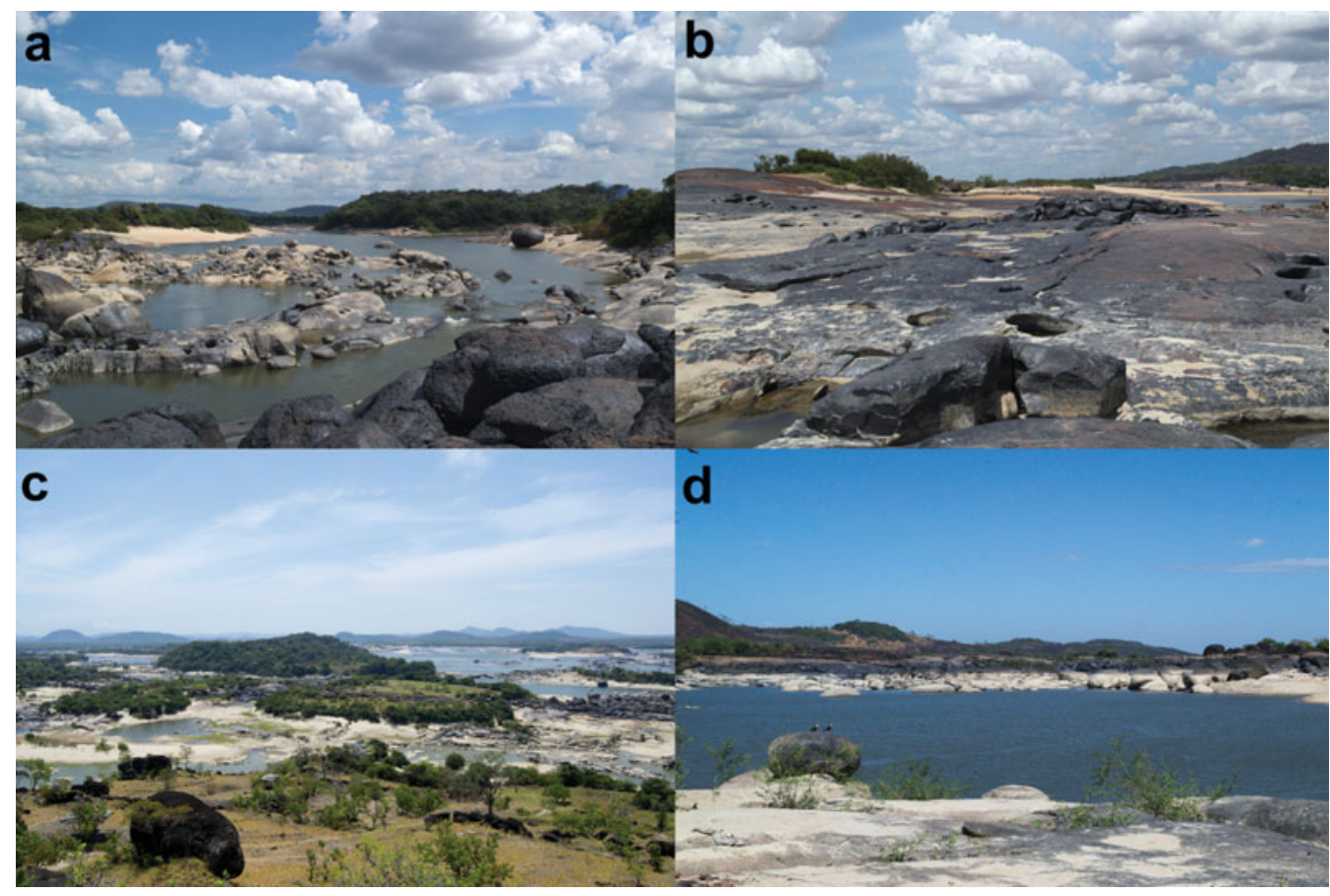

Figure 2. The Atures Rapids. a) View of Raudal Wayuco and Picure (background), facing south; b) Raudal Yavariven looking west, $c$ ) overview of the Atures Rapids from mainland Venezuela (photograph by José Oliver); d) view from Picure looking north towards Cotúa.

engraving from Raudal Yavarivén were also subjected to data capture with polynomial texture mapping (PTM) to provide an additional record of production techniques (excision, incision, pecking) for motifs of particular interest (see Duffy et al. 2013; Riris \& Corteletti 2015). The data discussed in this article is available as supplementary information in Riris et al. (2017).

\section{Taphonomy and spatial organisation}

The formation processes affecting the corpus, and hence the placement of engravings in relation to the river, are central to understanding it as a whole. The bedrock of the islands is composed entirely of hard Precambrian granite typical of the western Guiana shield (Gaudette et al. 1978), forming large tabular outcrops that are capped with relatively thin Quaternary deposits of silty sand in the island interiors. Although hard and coarse-grained, the exposed geology is subject to cyclical stress through a combination of insolation, precipitation and the life cycles of epilithic algae. The latter lends many rocks a black patina (Huber \& Zent 1995; Crispim \& Gaylarde 2005). In addition to these biotic and abiotic weathering factors, almost all of the engravings found in the Rapids are inundated and exposed to varying degrees by seasonally rising and falling water levels in the Orinoco. Depending on fluctuating upstream precipitation, the relative height of the river also varies annually by up to several metres during the extremes of both seasons. Consequently, in

(C) Antiquity Publications Ltd, 2017 
Table 1. Motif counts for the eight principal groups of engravings in the Atures Rapids.

\begin{tabular}{lccccccccc}
\hline & & \multicolumn{9}{c}{ Animal } & & & & & & \\
\cline { 3 - 6 } Site & Human & Profile & Plan & Scroll & Modern & Dots & Geometric & Other & Total \\
\hline Wayuco & 3 & 0 & 0 & 0 & 1 & 0 & 8 & 2 & 14 \\
$\begin{array}{l}\text { Cotúa } \\
\text { Picure }\end{array}$ & 0 & 2 & 0 & 0 & 0 & 0 & 1 & 0 & 3 \\
$\quad$ East & 5 & 26 & 6 & 8 & 2 & 1 & 26 & 18 & 92 \\
$\quad$ West & 8 & 3 & 0 & 11 & 0 & 0 & 15 & 6 & 43 \\
$\quad$ Lower & 1 & 0 & 5 & 3 & 0 & 0 & 2 & 1 & 12 \\
Yavarivén & 5 & 1 & 0 & 3 & 1 & 2 & 12 & 6 & 30 \\
Zamuro & 0 & 3 & 0 & 2 & 1 & 1 & 2 & 1 & 10 \\
Roca Sagrada & 0 & 0 & 0 & 0 & 0 & 0 & 4 & 1 & 5 \\
Total & $\mathbf{2 2}$ & $\mathbf{3 5}$ & $\mathbf{1 1}$ & $\mathbf{2 7}$ & $\mathbf{5}$ & $\mathbf{4}$ & $\mathbf{7 0}$ & $\mathbf{3 5}$ & $\mathbf{2 0 9}$ \\
\hline
\end{tabular}

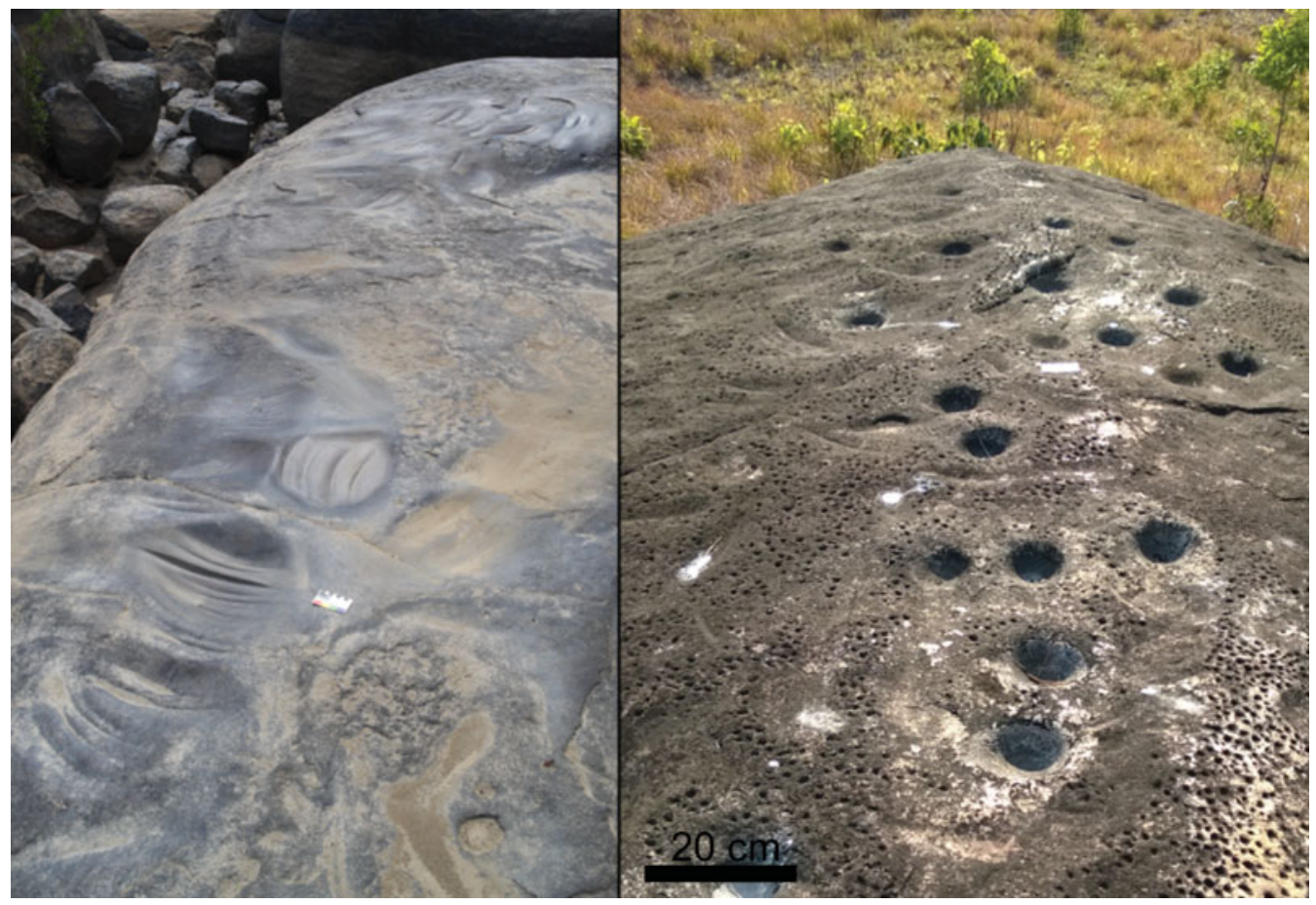

Figure 3. Axe polishers (left) and cupules (right) recorded on Picure (80mm photographic scale on the left).

any given year, certain panels may never be inundated, while others may never be exposed. The duration and intensity of contact that engravings have with flowing water also varies. Their orientation and local topography, therefore, strongly affect the relative degree of preservation (as observed by Williams (1985: 339)).

Differences were observable between engraved motifs located at comparable heights above the water $(<0.5 \mathrm{~m})$ in the fast-flowing main channel of the Orinoco and the more meandering side channels of the Rapids. Figure 6 illustrates the low-lying panel (C) Antiquity Publications Ltd, 2017 


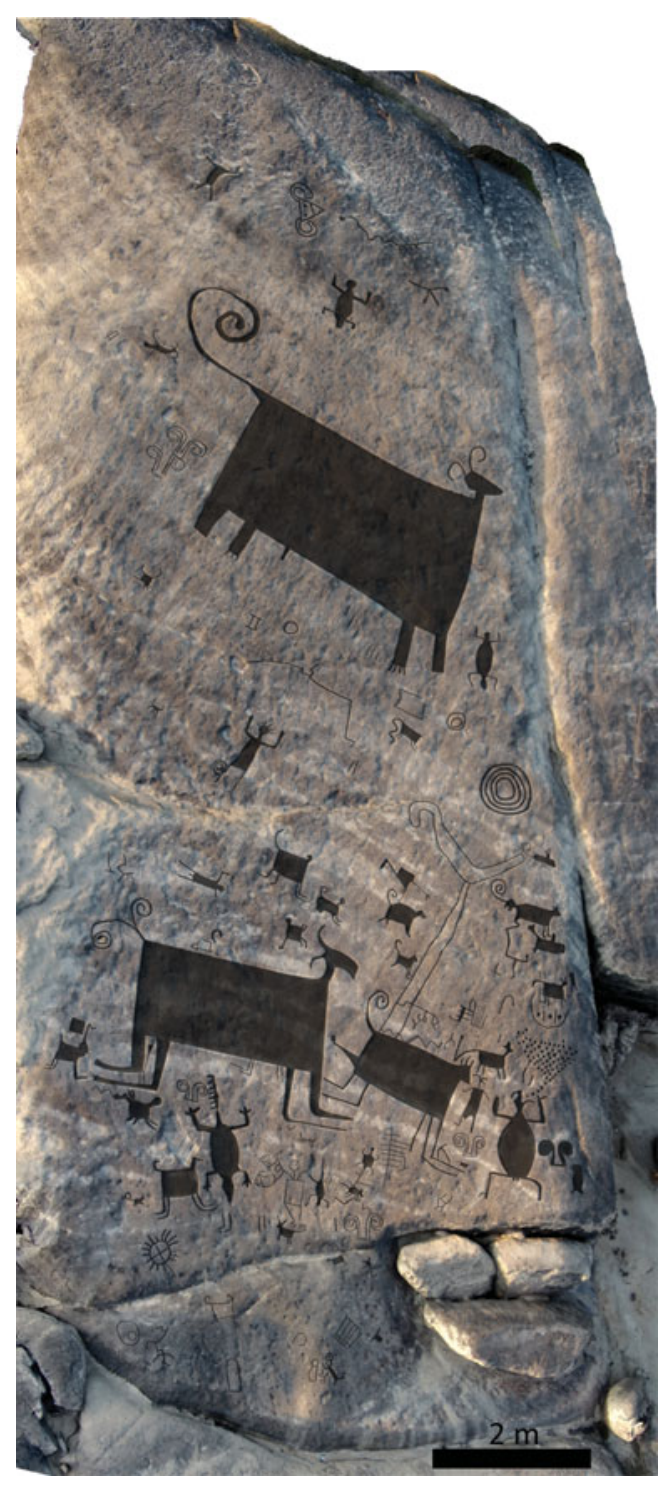

Figure 4. Top-down aerial perspective of east panel on Picure, with interpretative overlay of main engravings. North is at the bottom of the image. on Picure (a) alongside motifs in Raudal Yavarivén $(b-c)$, all of which were exposed during the peak of a drier-than-average season. The bedrock in Yavarivén is smoothed and the engravings, produced by incision and pecking, are relatively shallow. Thus, these motifs were probably severely eroded over time, and some are almost completely destroyed. Conversely, the edges of the engravings (excised, incised and pecked) around the sides of Picure are sharp and well defined. The rock in these two locations is identical. Despite the pockmarked appearance of the laja on Picure, there is no evidence of partially preserved motifs where the rock has formed small laminar fractures typical of the local geology. These two fluvial zones share stylistic content (dots, concentric circles, opposed scrolls, human figures and animal profiles), suggesting that some of the motifs were probably produced at roughly similar times, and have been exposed for comparable timescales.

A parsimonious explanation for observed variability in the condition of the engravings is differential exposure to turbulent water: even under extreme drought conditions Raudal Yavarivén has highspeed flows running through portions of it. During wetter years, these flows would also cover most areas with engravings in this part of the Rapids. Engravings on the north side of Picure, however, are located in the draft of the island itself; they are subject to relatively slow flows, thereby explaining the good preservation of even shallow motifs.

Similarly, engravings in Raudal Wayuco, to the immediate north-west of Picure, are placed both in the open and sequestered in rockshelters. Comparable differences can be observed within this cluster (Figure 7). The engravings recorded in the Rapids probably represent a small proportion of the original extent of the corpus, noting also that two isolated panels of recorded pictographs are located well above the Orinoco high-water mark. Making engravings in areas that are seasonally flooded is typical across the whole of northern South America; seasonal exposure may be intimately linked to the usage

(C) Antiquity Publications Ltd, 2017 


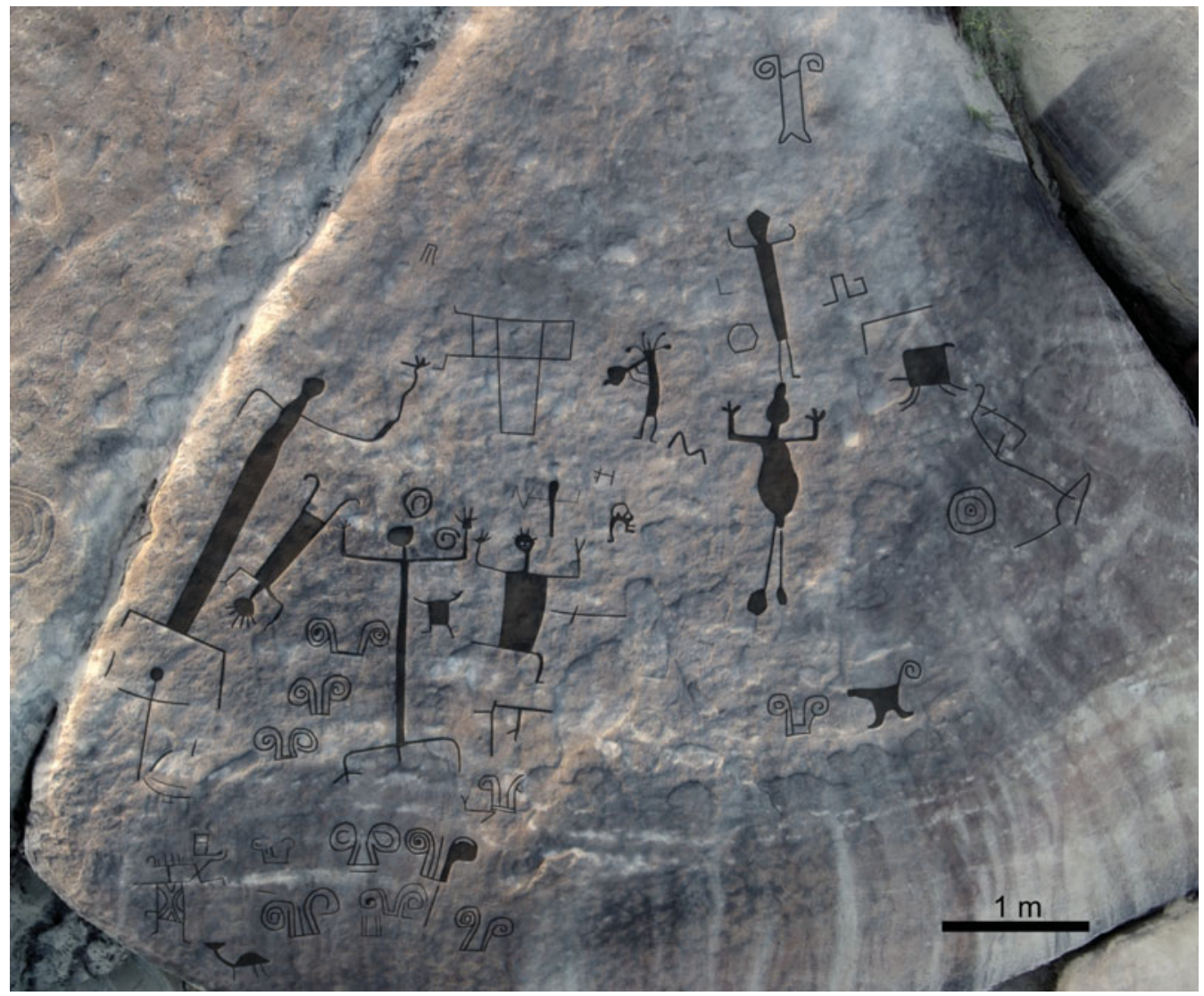

Figure 5. Oblique aerial view of western panel on Picure, with interpretative overlay of main engravings. North is at the bottom of the image.

or symbolism of engravings (see Im Thurn 1883; Koch-Grünberg 1921; Cruxent 1955; Williams 1985; Reichel-Dolmatoff 1987; Valle 2012). Detailed archaeological studies of riverine geomorphology are necessary to understand further the relationship between topography and surviving rock art.

\section{Chronology and authorship}

The broad timespan of putative human occupation of the Orinoco complicates the dating of this corpus. Cotúa, Zamuro and Picure Islands have extensive scatters of surface archaeology that include Barrancoid, Arauquinoid and Valloid ceramics. These represent extremities of the ceramic traditions defined in the Orinoco (Lozada Mendieta et al. 2016). The nearby site of Pozo Azul, on the right bank of the Orinoco, also has a pre-ceramic component associated with a radiometric date on charcoal of $8532-7836 \mathrm{cal} \mathrm{BP}$ at $95.4 \%$ probability (date modelled in OxCal v.4.3, using IntCal13 calibration curve, Beta-22638; Barse 1989; Bronk Ramsey 2009; Reimer et al. 2013). Superimposed motifs are rare in the Rapids, making relative dating challenging. Through close reading of the pictographic (C) Antiquity Publications Ltd, 2017 


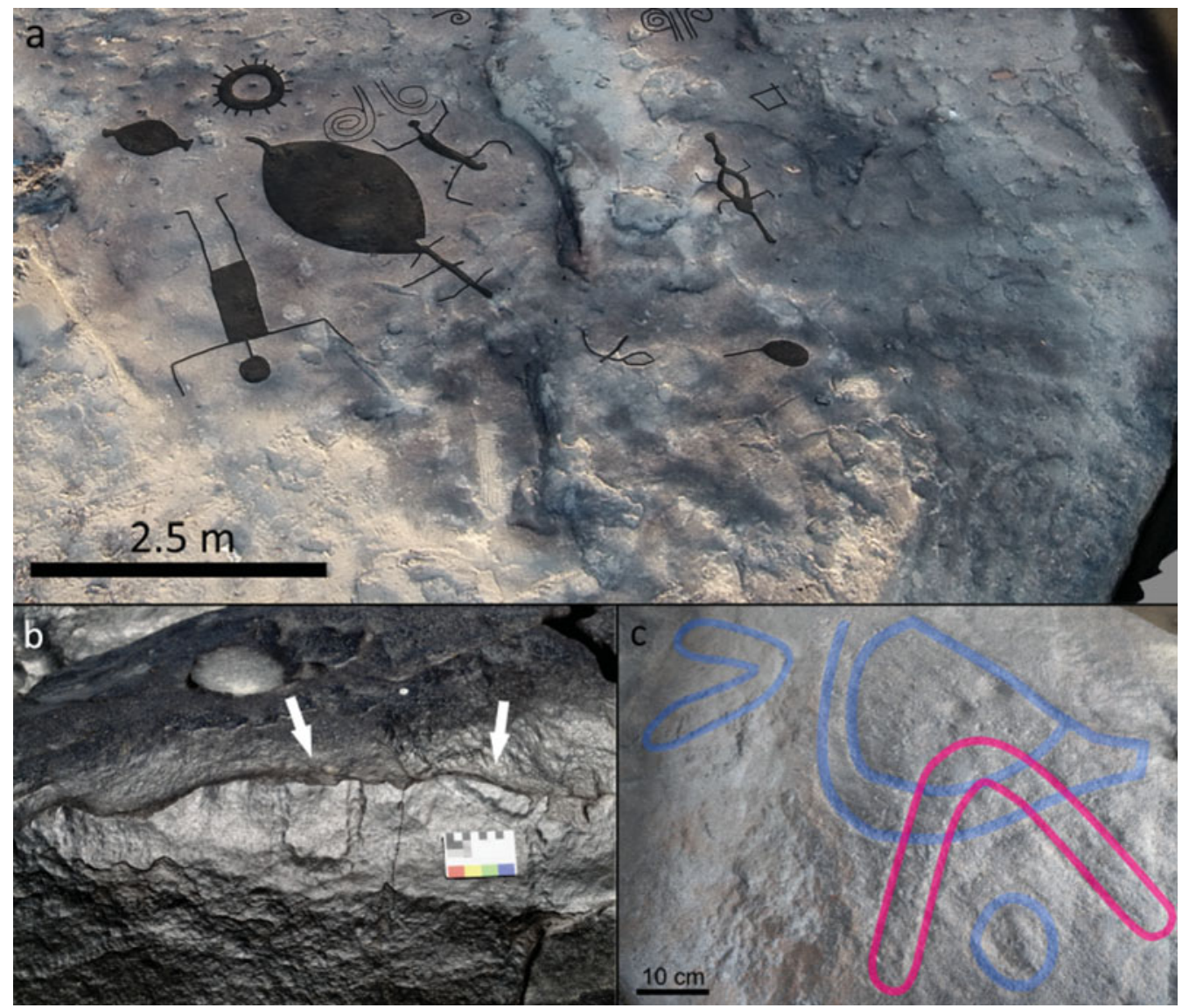

Figure 6. a) Oblique view of lower panel on Picure with good preservation; b) broken motif in Raudal Yavarivén; c) extremely eroded geometric motif in Raudal Yavarivén, captured with polynomial texture mapping and traced. Pink lines overlay blue.

record, Greer (1995) suggests seven successive phases for painted rock art spanning the Archaic to Colonial periods, and maps them on to major traditions in the Middle Orinoco. Although valuable on its own merit, this work lacks chemical or radiometric verification. Nor can it date petroglyphs by stylistic association. Tarble de Scaramelli and Scaramelli (2010) have tentatively correlated curvilinear motifs and the Saladoid/Barrancoid ceramic series (2500-700 BC/700 BC-AD 400, respectively), and rectilinear motifs (see Figure 7, left) and the Arauquinoid (AD 500-1500), all of which are present in the Rapids. They also note some similarities between sunken-relief animal and human motifs (see Figures 4-5) and Greer's Period 3 (Saladoid) pictographs (Tarble de Scaramelli \& Scaramelli 2012).

The ethnographic record of the Middle Orinoco has figured prominently in prior discussions of its pre-Columbian artistic corpus (see Greer 1995). Although native groups no longer produce pictographs or petroglyphs in the region, several groups historically used rockshelters with paintings as cemeteries, and attributed the creation of the paintings to 


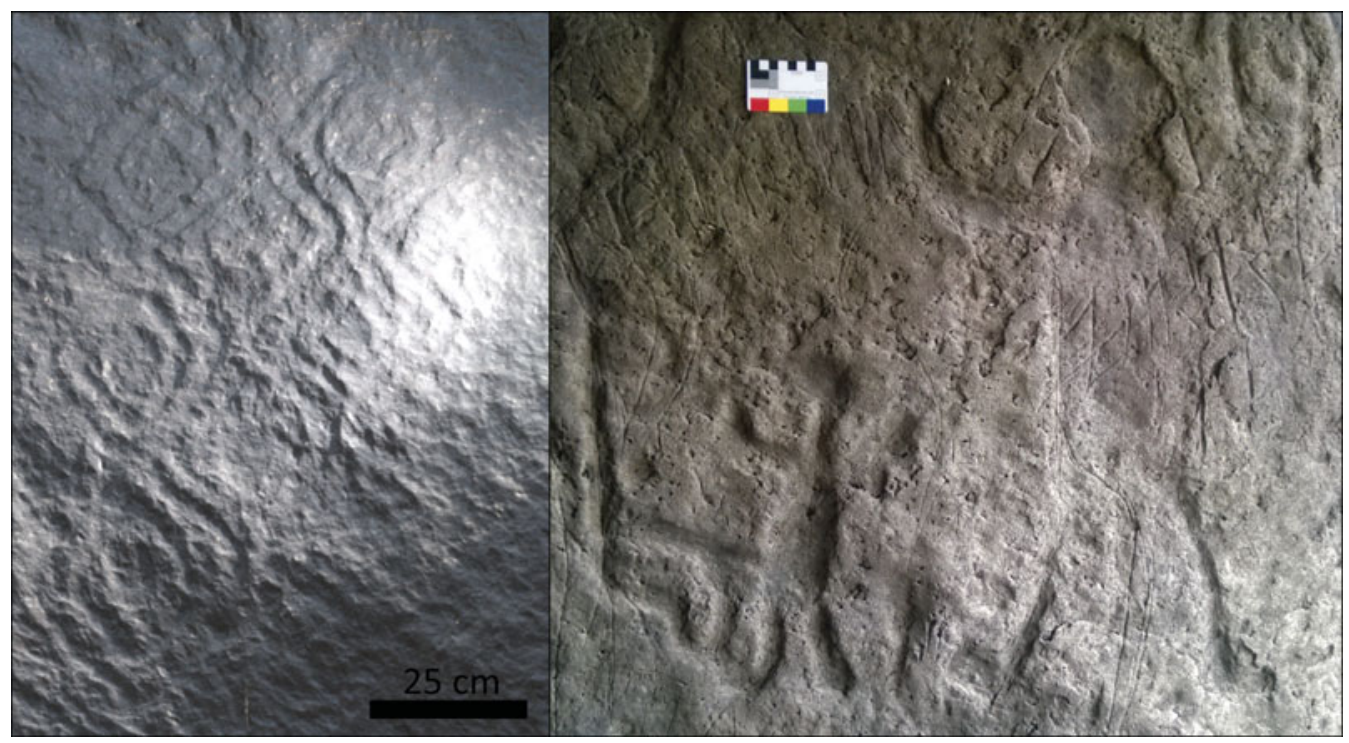

Figure 7. Severely eroded concentric lozenge motifs (left) and relatively well-preserved human figures in sunken relief (right) in Raudal Wayuco. Note modern vandalism (fine incisions, possibly made with metal tools) covering the former (80mm photographic scale on the right).

their ancestors (Marcano 1889; Scaramelli 1992). First-hand accounts of natives making engravings were documented in the Vaupés, north-west Amazonia, by Koch-Grünberg (1921: 144). Von Humboldt (1810) relates that engravings in Caicara were, according to native tradition, the work of ancestors drawing on young, soft rock. To interpret three extremely large horned snake motifs found in the Atures region (the Cerro Pintado example is $>30 \mathrm{~m}$ long: Figure 8), Tavera-Acosta (1956) cites a Sáliba myth describing the slaying of a monstrous serpent by the son of the creator deity and culture hero Wahari (Gumilla 1945[1745]: 111-12). The Piaroa worldview strongly distinguishes between benign and dangerous phenomena, and stresses the importance of ritual knowledge for safely mediating relations with the latter (Boglar 1976: 353, 1978; Overing 1996). Disease and death are caused by acting against prescribed conventions towards non-Piaroa agencies, which includes rock art (Marcano 1889: 393; del Rey Fajardo 1974: 174; Boglar 1978: 84; cf. Viveiros de Castro 1998). Historic attitudes towards petroglyphs in the region thus range from indifference to fear and reverence (Dubelaar 1986: 57-58). While some posited links are compelling, independent verification for the association of mythological accounts with specific panels and motifs remains elusive. Aspects of certain indigenous practices documented in the Middle Orinoco can nonetheless usefully inform us about the role of engravings in these societies, even if authorship cannot be ascertained.

\section{Indigenous myth and sacred topography}

In Piaroa cosmology, the Rapids are identified as both the birthplace of the sun and the residence of Wahari (Boglar 1978: 34). The cultural importance of the islands in this regard is reflected in the presence of specific motifs. Pre-Columbian engravings depicting flute

(C) Antiquity Publications Ltd, 2017 


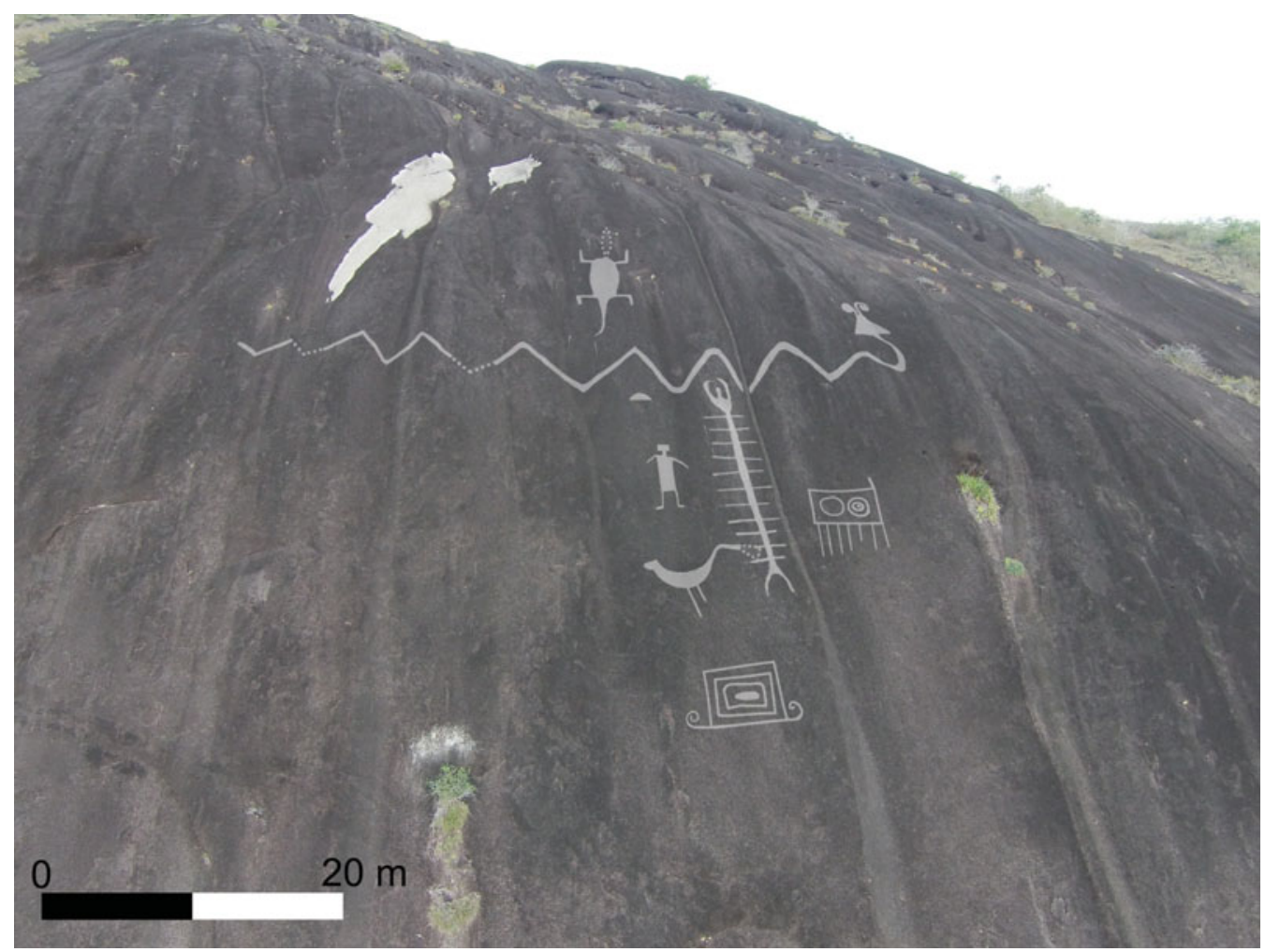

Figure 8. Aerial photograph of monumental Cerro Pintado petroglyphs with enhanced image overlay.

players in the Upper Negro-Vaupés basins have been linked to the Yuruparí ritual complex, a set of practices and material culture that includes several types of wind instruments (Valle 2012). The Yuruparí rite is most famously documented among Tukano and Arawak groups in western Amazonia (Koch-Grünberg 1921; Reichel-Dolmatoff 1978; Hugh-Jones 2016). Its northernmost expression is found among the Middle Orinoco Piaroa as the Warime ritual. The rites are seasonal and strongly male-gendered, and aim to protect the extended familial unit, ensure prolific agricultural production and re-establish the cosmological order (Mansutti Rodríguez 2012). Central components of these performances are interpreted in a literal manner. Specifically, the sound made by one of several types of flute is understood as the voice of Wahari. Ceremonial masks worn by participants are the actual presence of sacred animals joining the rites, as opposed to merely representing masks for individuals to wear (Boglar 1976: 348, 1978: 42; Mansutti Rodríguez 2012).

Myths and their ritual expression are viewed as more than performative in this context, as their effects for the participants are anchored in specific articles of material culture and iconographic elements, which possess their own agencies and identities (Viveiros de Castro 1998; Hugh-Jones 2016: 163). The motif of a flautist surrounded by other human figures from the main panel on Picure probably depicts part of a Yurupari/Warime-linked rite (Figure 9). Performances conceivably coincided with the seasonal emergence of the engravings from the river just before the onset of the wet season, when the islands are more

(C) Antiquity Publications Ltd, 2017 


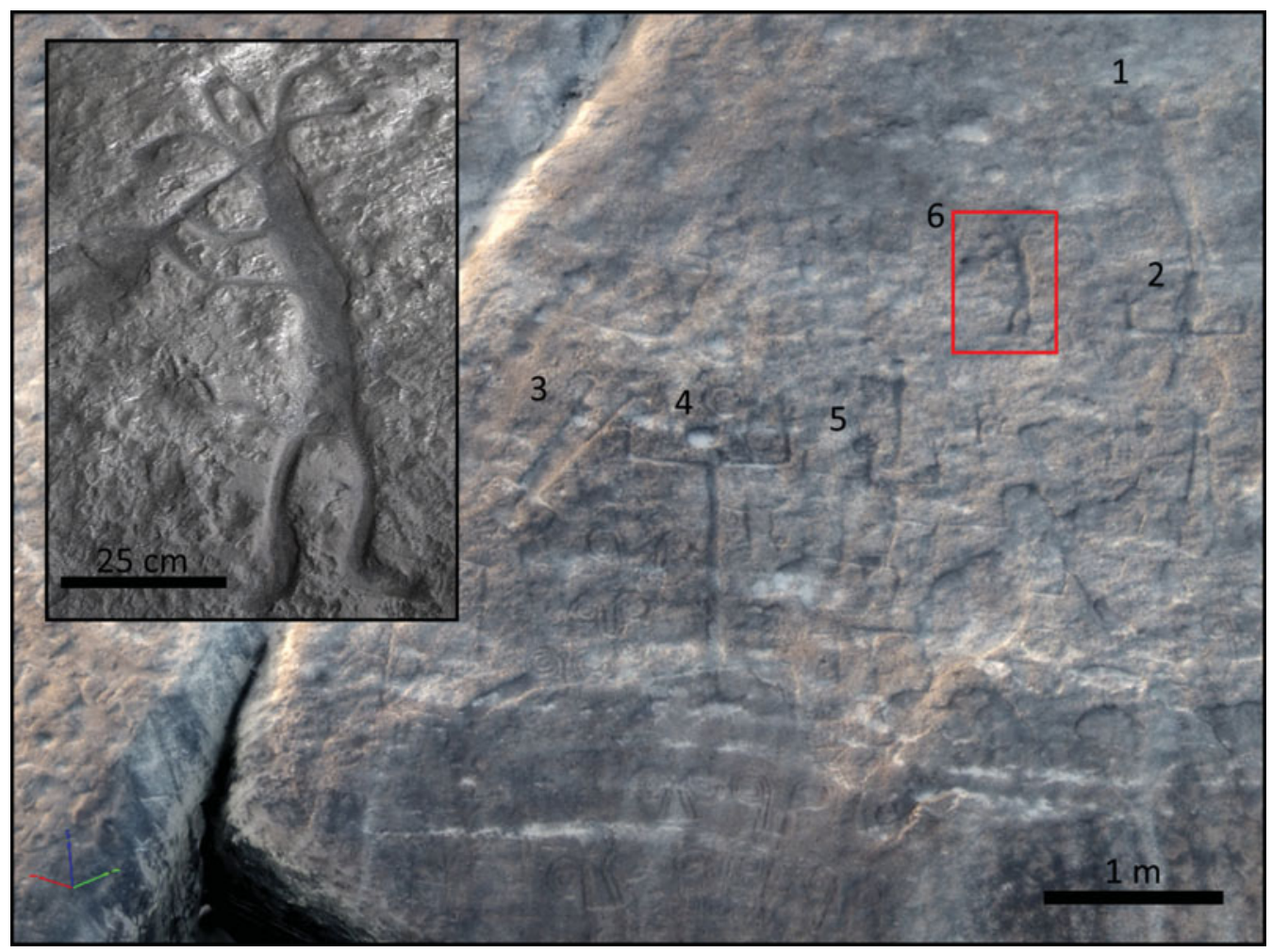

Figure 9. Six human figures on the western panel of Picure (see Figure 5), including a Yurupari flautist. Note that in the Vaupés region, opposed scrolls denote masculine energy (Reichel-Dolmatoff 1978). Inset: polynomial texture mapping detail of flautist.

accessible and the manioc harvest takes place (Zent 1992; Huber \& Zent 1995; Mansutti Rodríguez 2012: 64; Valle 2012). Although the majority of the Atures rock art corpus is cyclically submerged and exposed by the waters of the Orinoco (see Figure 1), the flautist panel is unique in that it can be linked to elements of recorded, extant indigenous practice. In light of the multi-period settlement site adjacent to the engravings, experiencing the rock art may be inextricably linked to the rhythm of their spatial context in the Rapids (Lefebvre 2004). While stylistic similarity between the rock art of the Orinoco and Amazonia is well attested (Williams 1985; Dubelaar 1986; Pereira 2001), this is the first instance where relationships can be established in terms of indigenous beliefs and local variations on shared practices (see Valle 2012). The archaeological and iconographic records together suggest that the Rapids were, and remain, a markedly significant topographic feature (SantosGranero 1998), connected to symbolic patterning far beyond their immediate setting.

Rock art was produced by both indigenous people and people of European descent throughout the Orinoco and northern South America (see Im Thurn 1883; Chaffanjon 1889; Koch-Grünberg 2010[1907]; Scaramelli 1992; Tarble de Scaramelli 2012). Close to the right riverbank, Raudal Zamuro hosts a large cross motif engraved in the centre of a cluster of seven pre-Columbian petroglyphs (Figure 10a). This is one of several non-indigenous (C) Antiquity Publications Ltd, 2017 


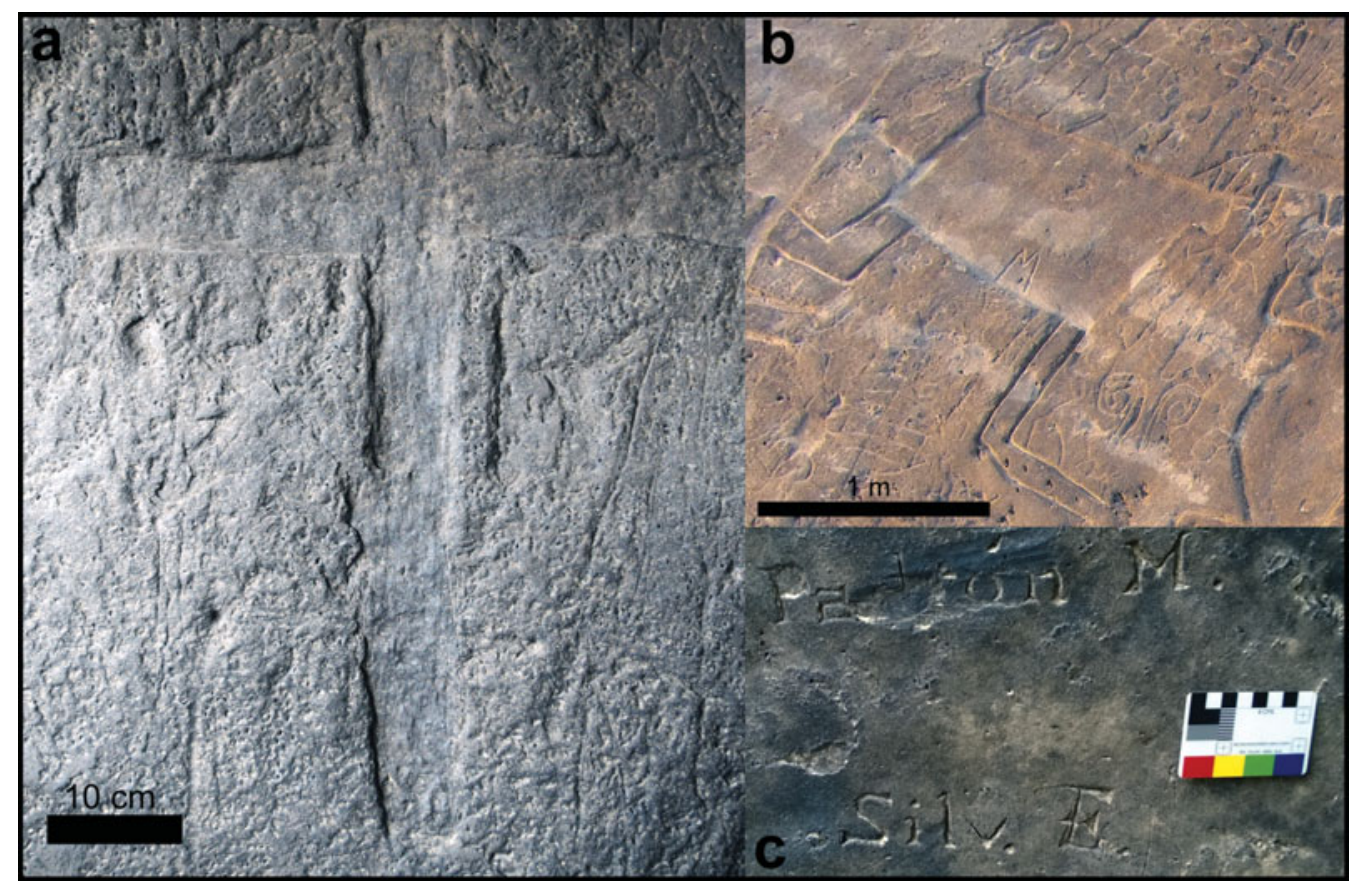

Figure 10. a) Colonial cross motif inserted among a group of indigenous motifs in Raudal Zamuro; b) oblique view of graffiti ' $M$ ' on an animal in profile on Picure (see Figure 4); c) early modern inscription in Raudal Wayuco.

motifs recorded in the Rapids (Figure $10 \mathrm{~b}-\mathrm{c}$ ). The area with the cross motif is easily accessible on foot during the dry season. As with rock art, powerful abilities were attributed to the missionaries by the natives. Historically, Jesuit fathers in the Middle Orinoco demonstrated their power to the mission populations whenever possible, in particular under perceived threat from the supernatural. In one notable account from the Tabaje mission between the Meta and the Rapids, blessings were said to be administered by the priest to protect against the spectre of a recently deceased member of the group (del Rey Fajardo 1966: 151). In another example pertaining directly to rock art, in 1691, missionaries visited a Sáliba "oracle" in the Atures region, which took the form of images located high on a hillside:

When our missionaries came to this place Satan was silenced at once, and the Devil disappeared from there, the diabolical responses ceasing henceforth with the astonishment and admiration of the pagans [...] whom before had treated with the demon so easily. With this the infidels knew the power of God, and the force and efficacy of the ministries against the powers of Hell (Rivero 1883: 284, translation by P.R.).

The cross motif fits within the historical trajectory of colonialism in the Orinoco from the seventeenth century onwards, and reveals the engagement of Christian individuals with the indigenous meanings attached to significant landscape features, such as the Rapids and Cerro Pintado. The insertion of the cross among native motifs is testament to the acknowledgement and endurance of native memories that surrounded rock art at this time. The need to contest these meanings materially was crucial during the

(C) Antiquity Publications Ltd, 2017 
evangelisation of the region. This directly parallels processes of spiritual exchange that have been documented through rock art elsewhere in the frontiers of early colonial America (see Recalde \& González Navarro 2015; Cooper et al. 2016), to which the Orinoco may now be compared.

\section{Conclusion}

Examining the corpus in light of the available archaeological and ethnographic information places the Rapids rock carvings within a long trajectory of interaction along the Orinoco watershed (Dubelaar 1986; Boomert 2000; Gassón 2002). Although no rock art in the region has been directly dated, there are clear links between its content and culturally significant indigenous beliefs across the pre-Columbian and Colonial periods. Consequently, this multifaceted corpus can be viewed as a local manifestation of a constellation of broadly comparable indigenous practices that spanned the Orinoco interaction sphere. This shared tradition of symbolic expression can be found in the arc bounded by the Vaupés River, the Guianas and the upper Negro (Williams 1985; Dubelaar 1986; Reichel-Dolmatoff 1987; Valle 2012). Certain common motifs, such as opposed scrolls, may have had context-specific meanings lost to time (cf. Reichel-Dolmatoff 1978; Williams 1985). Their similarity and recurrence along and within waterways, however, suggest that the people responsible for their production shared enduring norms on how to make use of engraved iconography to imbue the landscape with meaning, well into the Colonial period.

The diversity of motifs in the sample underscores the centrality of the Middle Orinoco landscape in mediating cultural contact between several regions. While painted rock art is principally associated with relatively remote funerary sites (see Scaramelli 1992; Greer 1995), engraved art is embedded in the everyday lived experience of travel and habitation in the Middle Orinoco River, including its rhythmic rising and falling, and its strong associations with important aquatic resources (Williams 1985: 380). With archaeological confirmation of long-term settlement on the islands (see Cruxent 1950; Lozada Mendieta et al. 2016), the corpus presented above can be placed within a complex social terrain that was inhabited by several different ethnolinguistic groups within an important zone of contact.

Close to the Rapids, previously documented sites such as Cerro Pintado and Cerro Paloma (left bank, opposite the Rapids) have some of the largest petroglyphs currently known in northern South America. The production of engravings on this monumental scale is a phenomenon apparently unique to the Middle Orinoco (see Tavera-Acosta 1956) — these motifs share stylistic elements with the Rapids. Future research will focus on linking the Rapids rock art to neighbouring regions through analytically explicit techniques (e.g. locational modelling and formal network analysis). Although the study area stands out in many respects, the corpus is clearly embedded in a broader supra-regional aesthetic tradition. It is undoubtedly the work of multiple authors working in significantly different cultural milieux and conditions. This necessitates clearer definitions of the many overlapping elements and characteristics discussed here, which will provide stronger models of the social roles played by rock art over time, across this vast region.

(C) Antiquity Publications Ltd, 2017 


\section{On confluence and contestation in the Orinoco interaction sphere}

\section{Acknowledgements}

This research was carried out under a Leverhulme Trust Research Grant (RPG-2014-234) obtained by project PI José Oliver. His help in the preparation of this paper is gratefully acknowledged, particularly regarding access to J.M. Cruxent's unpublished diaries. The fieldwork in Venezuela was made possible by support from the Instituto Venezolano de Investigaciones Cientificas, and from Juan Carlos García in Puerto Ayacucho. Tom Owen is also thanked for his insightful comments. Any errors are the author's responsibility.

\section{References}

BARSE, W.P. 1989. A preliminary archaeological sequence in the Upper Orinoco Valley, Territorio Federal del Amazonas. Unpublished PhD dissertation, Catholic University of America.

Boglar, L. 1976. Creative process in ritual art: Piaroa Indians, Venezuela, in A. Bharati (ed.) The realm of the extra-human. The Hague: Mouton. 347-54. https://doi.org/10.1515/9783110805871.347

- 1978. Cuentos y mitos de Los Piaroa. Caracas: Universidad Cátolica Andres Bello.

Boomert, A. 2000. Trinidad, Tobago and the Lower Orinoco interaction sphere: an archaeologicallethnohistorical study. Alkmaar: Cairi.

Bronk Ramsey, C. 2009. Bayesian analysis of radiocarbon dates. Radiocarbon 51: 337-60. https://doi.org/10.1017/S0033822200033865

Chaffanjon, J. 1889. L'Orénoque et le Caura. Paris: Hachette et Cie.

Cooper, J., A.V.M. Samson, M.A. Nieves, M.J. Lace, J. CaAmaño-Dones, C. Cartwright, P.N. Kambesis \& L. Del Olmo Frese. 2016. 'The Mona Chronicle': the archaeology of early religious encounter in the New World. Antiquity 90: 1054-71. https://doi.org/10.15184/aqy.2016.103

Costas Goberna, F.J., P. Novoa Alvarez \& M.C. FeRnÁNDEZ. 1996. Hacia una interpretación del arte rupestre de los primitivos actuales: aproximación al arte rupestre en los regiones del río Orinoco (Venezuela), in F.J. Costas Goberna \& J.M. Hidalgo Cuñarro (ed.) Los motivos geométricos en los grabados rupestres prehistóricos del continente europeo: 131-52. Vigo: Asociación Arqueológica Viguesa.

Crispim, C.A. \& C.C. Gaylarde. 2005. Cyanobacteria and biodeterioration of cultural heritage: a review. Microbial Ecology 49: 1-9. https://doi.org/10.1007/s00248-003-1052-5

Cruxent, J.M. 1950. The archaeology of Cotúa Island, Amazonas Territory, Venezuela. American Antiquity 16: 10-16. https://doi.org/10.2307/276336

- 1953. Diary of J.M. Cruxent, Orinoco. 12(2): 22 January 1953. Unpublished document: private collection.

- 1955. Petroglifos venezolanos. Revista 'A' Hombre y Expresión 2. del Rey Fajardo, J. 1966. Documentos jesuiticos relativos a la Compañía de Jesús en Venezuela, volume 1. Caracas: Academia Nacional de la Historia.

- 1974. Documentos jesuiticos relativos a la Compañia de Jesús en Venezuela, volume 2. Caracas: Academia Nacional de la Historia.

Dubelaar, C.N. 1986. South American and Caribbean petroglyphs. Dordrecht: Foris.

Duffy, S., P. Bryan, G. Earl, G. Beale, H. Pagi \& E. Kotoula. 2013. Multi-light imaging for heritage applications. London: English Heritage.

Gassón, R.A. 2002. Orinoquia: the archaeology of the Orinoco River Basin. Journal of World Prehistory 16: 237-311. https://doi.org/10.1023/A:1020978518142

Gaudette, H.E., V. Mendoza, P.M. Hurley \& H.W. Fairbairn. 1978. Geology and age of the Parguaza rapakivi granite, Venezuela. Geological Society of America Bulletin 89: 1335-40. https://doi.org/10.1130/00167606(1978)89<1335:GAAOTP > 2.0.CO;2

GiLIJ, F.S. 1965 [1782]. Ensayo de Historia Americana: Tomo III. Translated by A. Tovar. Caracas: Academia Nacional de la Historia.

GreER, J.W. 1995. Rock art chronology in the Orinoco Basin of southwestern Venezuela. Unpublished $\mathrm{PhD}$ dissertation, University of Missouri, Columbia.

Gumilla, J. 1945 [1745]. El Orinoco ilustrado y defendido. Historia natural, civil y geográfica de este gran río y de sus caudalosas vertientes. Translated by C. Bayle. Madrid: M. Aguilar.

Haviser, J.B. \& M. Strecker. 2006. Zone 2: Caribbean area and north-coastal South America, in Rock art of Latin America and the Caribbean: 43-84. Paris: ICOMOS.

Hornborg, A. 2005. Ethnogenesis, regional integration, and ecology in prehistoric Amazonia. Current Anthropology 46: 589-620. https://doi.org/10.1086/431530

Huber, O. \& S. Zent. 1995. Indigenous people and vegetation in the Venezuelan Guayana: some ecological considerations. Scientia Guaianae 5: 37-64. 
Hugh-Jones, S. 2016. Writing on stone; writing on paper: myth, history and memory in NW Amazonia. History and Anthropology 27: 154-82. http://dx.doi.org/10.1080/02757206.2016.113829

Im Thurn, E.F. 1883. Among the Indians of Guiana. London: Kegan Paul, Trench, \& Co.

Кoch-Grünberg, T. 2010 [1907]. Petróglifos Sul-Americanos. Translated by J.B. Poça da Silva. Belém: Museu Paraense Emílio Goeldi.

- 1921. Zwei Jahre bei den Indianern Nordwest-Brasiliens. Stuttgart: Strecker und Schröder.

Lathrap, D.W. 1970. The Upper Amazon. London: Thames \& Hudson.

Lefebvre, H. 2004. Rhythmanalysis: space, time and everyday life. London: Continuum.

Lozada Mendieta, N., J. Oliver \& P. Riris. 2016. Archaeology in the Átures Rapids of the Middle Orinoco, Venezuela. Archaeology International 19: 73-78. http://doi.org/10.5334/ai.1913.

Mansutti Rodríguez, A. 2012. Yuruparí: máscaras y poder entre los Piaroas del Orinoco. Espaço Amerindio 6: 46-75.

Marcano, G. 1889. Ethnographie précolombienne du Venezuela (région des Raudals de l'Orénoque). Bulletins de la Société d'anthropologie de Paris 12: 391-402. http://dx.doi.org/10.3406/bmsap.1889.6454

OJer, P. 1960. Don Antonio de Berrio, Gobernador de El Dorado. Caracas: Universidad Católica Andrés Bello.

Overing, J. 1996. Who is the mightiest of them all? Jaguar and conquistador in Piaroa images of alterity and identity, in A.J. Arnold (ed.) Monsters, tricksters, and sacred cows: 50-79. Charlottesville: University Press of Virginia.

Pereira, E. 2001. Testimony in stone: rock art in the Amazon, in C. McEwan, C. Barreto \& E. Neves (ed.) Unknown Amazon: 214-31. London: British Museum.

Recalde, A. \& C. González Navarro. 2015. Colonial rock art: a reflection on resistance and cultural change $\left(16^{\text {th }}\right.$ - and $17^{\text {th }}$-century Córdoba, Argentina). Journal of Social Archaeology 15: 45-66. http://dx.doi.org/10.1177/1469605314548940

Reichel-Dolmatoff, G. 1978. Beyond the Milky Way. Los Angeles (CA): UCLA Latin American Center Publications.

- 1987. Shamanism and art of the Eastern Tukanoan Indians. Leiden: E.J. Brill.
Reimer, P.J., E. Bard, A. Bayliss, J.W. Beck, P.G. Blackwell, C. Bronk Ramsey, C.E. Buck, H. Cheng, R.L. Edwards, M. Friedrich, P.M. Grootes, T.P. Guilderson, H. Haflidason, I. Hajdas, C. Hatté, T.J. Heaton, D.L. Hoffmann, A.G. Hogg, K.A. Hughen, K.F. Kaiser, B. Kromer, S.W. Manning, M. Niu, R.W. Reimer, D.A. Richards, E.M. ScotT, J.R. Southon, R.A. Staff, C.S.M. Turney \& J. van Der Plicht. 2013. IntCal13 and Marine13 radiocarbon age calibration curves $0-50,000$ years cal BP. Radiocarbon 55: 1869-87. https://doi.org/10.2458/azu_js_rc.55.16947.

Riris, P. \& R. Corteletti. 2015. A new record of pre-Columbian engravings in Urubici (SC), Brazil, using polynomial texture mapping. Internet Archaeology 38: https://doi.org/10.11141/ia.38.7.

Riris, P., J. Oliver \& N. Lozada Mendieta. 2017. Supplementary data. On confluence and contestation in the Atures Rapids. figshare. https://dx.doi.org/10.6084/m9.figshare.c.3772352.

Rivero, J. 1883. Historia de las misiones de los Llanos de Casanare y los ríos Orinoco y Meta. Bogotá: Imprenta de Silvestre y Compañia.

Rostain, S. 2014. Islands in the rainforest: landscape management in pre-Columbian Amazonia. Walnut Creek (CA): Left Coast.

Santos-Granero, F. 1998. Writing history into the landscape: space, myth, and ritual in contemporary Amazonia. American Ethnologist 25: 128-48. https://doi.org/10.1525/ae.1998.25.2.128

SCaramelli, F. 1992. Las pinturas rupestres en el Parguaza: mito y representación. Unpublished BA dissertation, Universidad Central de Venezuela.

Sujo Volsky, J. 1975. El studio del arte rupestre en Venezuela. Caracas: Universidad Católica Andres Bello.

Tarble, K. \& F. Scaramelli. 1999. Style, function, and context in the rock art of the Middle Orinoco area. Boletín de la Sociedad Venezolana de Espeleología 33: 17-33.

Tarble de Scaramelli, K. 2012. Effects of empire: gendered transformations on the Orinoco frontier, in B.L. Voss \& E. Conlin Casella (ed.) The archaeology of colonialism: 138-55. Cambridge: Cambridge University Press.

Tarble de Scaramelli, K. \& F. Scaramelli. 2010. El arte rupestre y su contexto arqueológico en el Orinoco Medio, Venezuela, in E. Pereira \& V. Guapindaía (ed.) Arqueologia Amazonica: 285-315. Belém: Museo Paraense Emilio Goeldi.

- 2012. Recent rock art research in Venezuela, in P. Bahn, N. Franklin \& M. Strecker (ed.) Rock art studies: news of the world IV: 329-37. Oxford: Oxbow. 
Tavera-Acosta, B. 1956. Los petroglifos de Venezuela. Caracas: Universidad Central de Venezuela.

VALLE, R. 2012. Mentes graníticas e mentes areníticas: fronteira geo-cognitiva nas gravuras rupestres do Baixo Rio Negro, Amazonia Setentrional. Unpublished PhD dissertation, Universidade de São Paulo.

Viveiros de Castro, E. 1998. Cosmological deixis and Amerindian perspectivism. Journal of the Royal Anthropological Institute 4: 469-88. https://doi.org/10.2307/3034157

von Humboldt, A. 1810. Vues des Cordillères et monuments des peuples indigènes de l'Amérique. Nanterre: Erasme.

Williams, D. 1985. Petroglyphs in the prehistory of northern Amazonia and the Antilles, in F. Wendell \& A.E. Close (ed.) Advances in world archaeology 4: 335-87. New York: Academic.
ZENT, S. 1992. Historical and ethnographic ecology of the Upper Cuao River Wothuha. Unpublished PhD dissertation, Columbia University.

Zucchi, A. 2002. A new model of the northern Arawakan expansion, in J.D. Hill \& F. Santos-Granero (ed.) Comparative Arawakan histories: rethinking language family and culture area in Amazonia: 199-222. Chicago: University of Illinois Press.

- 2010. Antiguas migraciones Maipures y Caribes: dos áreas ancestrales y diferentes rutas, in E. Pereira \& V. Guapindaía (ed.) Arqueologia Amazonica: 111-35. Belém: Museu Paraense Emilio Goeldi.

Received: 14 September 2016; Accepted: 17 January 2017; Revised: 18 April 2017 